\title{
EARTH'S FORMATION FROM THE QURANIC PERSPECTIVES BASED ON SURAH AL-RA'D VERSE 3
}

\author{
Mohamed Akhiruddin Ibrahim \\ Dr., Universiti Sains Islam Malaysia, MALAYSIA, akhiruddin@usim.edu.my
}

\begin{abstract}
Quran is a book which is perfect in various aspects. In Surah Ar-Ra'd verse 3 in the Quran tells us that the supernatural and the power of governing and administering only just from Allah SWT. It emphasizes that no one has the knowledge of the unseen and the power of governing nature except Allah SWT. The study was conducted to disseminate and analyze the discussion behind verse 3 Surah Ar-Ra'd. This verse proves the fact that only Allah SWT creates earth, mountains, rivers, night and day and it beyond one's imagination or power. The objective of this study is to study how Islamic scholars and scientists make an explanation about the formation of earth without the existence of pillars such as mountains, rivers as water sources to earth and the occurrence of day and night. In doing research, there are few methods to collect the data. First is scientific study and the second is field research, both qualitative approaches. Qualitative methods that were used are books, journals and articles obtained from library research. By using the qualitative method, it helps the researcher to gain more information from any sources that recognized and reliable. From the result obtained, the researcher retrieved the scholars and scientists' explanation on the earth's formation as related in Surah Ar-Ra'd verse 3.
\end{abstract}

Keywords: Surah Ar-Ra'd, earth, mountain, river, day and night

\section{INTRODUCTION}

Quran is a perfect guidance in various aspects of life for human being. Reading the Quran and practicing is part of the act of worship. It is a revelation that God sent down to the Prophet Muhammad SAW through Jibril AS. It is a holy book for Muslims. It is a book of human life guidance and a major reference of Muslims besides the Hadith of Prophet Muhammad SAW. Besides, in Quran it has many discoveries that are not reveal yet. For example, in Quranic verses, it has explanations on Lailatulqadar that was revealed to Prophet Muhammad SAW gradually for 23 years. Therefore, as a human being, it is vital for us to uncover the miracle of Quran's content to interpret it better for us to refer it as our guidance. Significantly, the development of studying Quran has emerged to a new pattern in interpreting it. In general, the interpretation is along in line with science knowledge that describes the verse of Quran and describes the purpose of the verse in accordance to human ability. Tafsir IImi is one of the way in studying and interpreting as to unravel the virtues of Quran as the source of appropriate science at all times (Udi, 2011).

Surah Ar-Ra'd is the 13th surah in the Quran and consists 43 verses. This surah is a Makkiyyah surah and called Ar-Ra'd which means thunder because in verse 13, Allah says that "And the thunder glorifies and praises Him". This verse shows the nature of holiness and perfection of Allah SWT and accordance with the nature of the Quran containing the threat and hope, then that's the sound of thunder that creates anxiety and hope for humans. The most important content of this surah is that God's guidance to His creatures is closely 
related to causality and law. There is no favor in determining punishment for Allah SWT in fact, the reply or punishment is the result and obedience or disobedience of God's law.

The arguments in this surah is a type of warning. It is not the same as other surah. This surah wants to tell about the supernatural and the power of managing and administering it from Allah. It emphasizes that no one else has this supernatural and governing authority. There are two elements that are emphasized in this surah which is knowledge and tasarruf. Surah Ar-Ra'd verse 3 tells the miracle of the creation and proves the fact that only Allah SWT can creates heaven, mountains, rivers, day and night and this is a greatness for those who think. The verse of this surah shows that Quran already proves about the creation of earth and sky before scientist's findings (Celik Tafsir, 2017).

\section{LITERATURE REVIEW}

Based on the past research, researchers found that some studies have been conducted and have a relation to this topic. The researcher takes the opportunity to get more information regarding this study based on several researches as stated:

Firstly, Danial (2014) in updated edition of 'Quran Saintifik' claims about the majesty of God and the greatness of the Quranic miracles through Islamic and science glasses. The book also reveals in details on the latest scientific research and phenomena of science that proved by Quran. Next, article about the basic geology of earth formation theory tells about the history of the earth's formation and knowing the factors that encourage the formation of it (Allan, 2015). Ahmad (2011) in his thesis describes about the balance of earth's creation according to Quran and science. The creation of the earth is a creation of God in perfection and equality. Every creation of earth process is a sign of greatness for those who think.

In addition, Rizki (2015) reveals the theory of earth and sky creation discussed in Tafsir Al-Jawahir by Tantawi Jauhari. This thesis reveals the creation of earth and sky from scientific and Islamic views through verses in Quran. The writer of the thesis chooses Tafsir Al-Jawahir because the book has a complete information of science data creation to study the creation of earth and sky. According to the writer, Tantawi's opinion about the creation of earth and sky is tended to the theory of Big Bang by Edwin Hubble. Besides, Fuad (2016) also discusses about Tafsir Al-Jawahir but focused on the functions and role of mountains. Next, the events of day and night occur because only part of the earth is facing towards the sun when it rotates on its orbit. The area of the earth facing the sun will experience daylight, while the backward area will experience night. As the earth rotates from the west of the east, the eastern part of the earth will receive sunlight or experience daylight first than the west (Aleevia, 2013).

\section{RESEARCH METHODOLOGY}

The word methodology comes from Greek consisting of two words "methodos" and "logos". Methodos means the way or technique and style of a study. Research is defined as a systematic data collection and analysis activity to break a question in the mind. There are two types of research methods: qualitative and quantitative. The researcher using qualitative research method because qualitative is a data in the form of information from identified sources. Qualitative data is available from books, journals, articles and pictures. A qualitative method that was used by researcher is books, journals and articles obtained from library research. Researcher also used the library study and it was conducted to study and find material references to obtain the necessary information about Surah Ar-Ra'd verse 3 through books, journals, articles and other references. By using the qualitative method, it helps the researcher to gain more information from any sources that recognized. Besides, it also the easy way to collect the data rather than the quantitative method. From the other side, the researcher can analyze all the information after collect and gather all the data.

\section{DISCUSSION}

Quran is a revelation that God, Allah SWT, sent down to the Prophet Muhammad SAW through Jibril AS. Allah SWT has revealed the Quran as a miracle which proves the Prophet Muhammad SAW, and the existence of Allah SWT with all the attributes of His perfection. In addition, Quran tells a lot about science that needs to be studied and perceived by humans and how it is created. As in Surah Ar-Ra'd verse 3 said about the creation of earth and also tells about mountain and river that people should study and know. In this verse also tells about the creation of day and night and how this phenomenon happened.

\subsection{Earth}

\subsubsection{Definition of Earth}

Earth is a planet that being in the third order from the sun and the fifth largest planet of all planets. Earth can 
also be as a home to all living beings that experiences rotation and revolution. Earth takes about 24 hours to make a full rotation in its orbit while the revolution turning around the sun which takes about 365 days. The rotation of earth may result day and night shifts and the occurrence of time differences between different countries while the revolution resulted in seasonal change in all continents in the world and changing the time of day and night (Ilmu Geografi, 2016).

In addition, earth is a planet that surrounds the sun with a distance of 149.6 million $\mathrm{km}$. The diameter of the earth is about 17,560 km while the mass of the earth is about 598x 1000ton (Budianto, 2006). Earth is closest state to the sun in January with a distance of 147.0 million $\mathrm{km}$ and the farthest distance is about 152.0 million $\mathrm{km}$ on six months later (Stuart, 2008).

\subsubsection{Earth Layer}

The earth has 3 layer structured as follows (Abdul, 1996):
1) Crust
2) Mantle
3) Core earth

The first layer is Crust. Crust is an outer shell (surface of the earth) with a mass of $0.3 \%$ of the total mass of the earth. The thickness of the crust layer reaches $70 \mathrm{~km}$ as a rock layer composed with rocks and sandstones. This layer is as a home to all living things. The temperature at the bottom of the crust reaches $1.100{ }^{\circ} \mathrm{C}$ and the top layer of the crust is called lithosphere (Linda, 2012).

Next, the second layer is Mantle. Mantle is a layer that lies beneath the crust layer or can be found on the layer of nife (niccolum = nickel and ferrum = iron). Mantle is also called intermediate layer or asthenosphere and has a high temperature liquid and incandescent. The thickness of the layer reaches 2,900 km and its average weight is $5 \mathrm{gr} / \mathrm{cm}$ while the temperature at the bottom of the earth blanket reaches $3,000{ }^{\circ} \mathrm{C}$. In addition, mantle is a source of melting rocks that become volcanic magma which are made from magnesium, silicon, oxygen, iron and aluminum (Budianto, 2006).

The last layer is called Core Earth (line or core). Core earth is a solid material composed of a layer of nife (niccolum $=$ nickel and ferrum $=$ iron). The existence of this nickel and iron material has caused a great magnetism. Moreover, the core layer is divided into outer core and inner core. The outer core is about 2,000 $\mathrm{km}$ thick and consists of a liquid plant with temperature reaches about $2.200^{\circ} \mathrm{C}$ while the inner core is a ballcentered with a diameter of $2,700 \mathrm{~km}$ and consists of darine and iron with the temperature reaches $4,500{ }^{\circ} \mathrm{C}$ (Linda, 2012).

\subsubsection{The Formation of Earth According Quran}

Quran does not much mentioned about the formation of earth itself. Therefore, there is a support of the explanation of the creation of sky and earth when it was first created. In fact, the creation of the earth does not take six days as it is found in Surah Fussilat verse 9-11:

"Say, 'Do you really disbelieve in Him who created the earth in two days and ascribe partners to Him? That is the Lord of all the worlds!' (9) He set in it firm mountains [rising] above it, and blessed it and ordained therein its [various] means of sustenance in four days, alike for all the seekers [of the means of sustenance] (10) Then He turned to the heaven, and it was smoke, and He said to it and to the earth, 'Come! Willingly or unwillingly!' They said, 'We come heartily (11)" (Surah Fussilat verse 9-11)

In addition, Quran also discussed about the creation of sky and earth within six days as in Surah As-Sajdah verse 4:

"It is Allah who created the heavens and the earth and whatever is between them in six days then He settled on the Throne. You do not have besides Him any guardian or intercessor. Will you not then take admonition?" (Surah As-Sajdah verse 4)

There are also explanations about the chronology of sky and earth creation in six phase discussed in Surah An-Nazi'at verse 27-33:

"Is it you whose creation is more prodigious or the sky which He has built?(27) He raised its vault, and fashioned it (28) And darkened its night, and brought forth its day (29) And after that He spread out the earth (30) And brought forth from it its water and pastures (31) And set firm the mountains (32) As a [place of] sustenance for you and your livestock (33)" (Surah An-Nazi'at verse 27-33)

First: Verse 27 described the creation of the universe with a process called Big Bang (a big explosion) as the 
first sign of the formation of space and time.

Second: Verse 28 explained the expansion of the universe and gives understanding about the formation of the sky is not the first process but the evolutionary process.

Third: Verse 29 described the existence of the solar system that also occur to the other stars and also discussed the creation of the sun that shining the earth rotation in forming day and night.

Fourth: Verse 30 explained the process of earth's evolution and described the earth was stranded.

Fifth: Verse 31 stated that early creation of life on earth is by providing water.

Sixth: Verse 32 and 33 explained about mountains arise as an effect of geological evolution and the creation of animals and humans (Lajnah Pentashihan Mushaf Al-Quran, 2010).

The theory of earth's formation is from the accretion process according to Otto Schmidt's view. He is a geophysical expert from Russia and the theory that he created became popular today. The process of earth's formation is through a particular phase as in Surah Az-Zukhruf verse 10, Allah explains that "He made the earth for you as a dwelling place and He made roads for you on earth so that you might be guided". In this verse, Allah uses the word "mahda" when narrating the earth. According to Hans Wehr, the word comes from "mahada" which means to spread out evently or to make easy (Cowan, 1979). This analogy describes the earth as a spreadsheet to facilitate human's activity on the earth (Danial, 2014).

Then, in Surah Ar-Ra'd verse 3, Allah explains "And He is the God who stretched out the earth and made the mountains and rivers in it. And to him all the fruit of pairs. Allah closet the night to day. Verily in these are Signs for people who think". In this verse, Allah uses the word "madda" and according to Hans Wehr, the meaning of it is to extend, distend, expand, dilate and stretch. This verse shows the earth is not static but continues to widen and grow and this will defend the opportunity used by infidels who say that the Quran is not scientific because these verses indicate that the earth is flat and not sphere (Danial, 2014).

\subsection{River}

\subsubsection{The Importance of The River for The Earth}

Water can be found almost everywhere in the world as it is one of the most important sources of life for human being. Therefore, human, animals and plants on earth cannot live without water. In addition, the earth can store enough water for living things on the earth due to the accurate gravity as water is one of the most abundant molecules on earth. There are about 350 million cubic kilometers of water in this planet where $97 \%$ of the water is found in the ocean which includes two-thirds of the planet's surface area. Approximately $90 \%$ are frozen ice in the north and south poles and as much as $1 \%$ of all the water in the earth is available in consumption and most are found in underground aquifers. Besides, oxygen is very important for human and it is one of the elements of water that consists approximately $70 \%$ of human body (Lerner \& Lerner, 2004).

A. E. Needhem a biochemist shows on how important of life's formation. If the law of the universe only allows the existence of solids and gas, then there will never be a life. The reason is that the atoms of solid matter binds too closely and too static as in no way allows the dynamic molecular process to be important for the occurrence of life. In fact, the atoms move freely in the gas and the complex life-forms mechanism is not functions in such a structured. Therefore, the liquid environment is absolutely necessary for the formation of life. In conclusion, this object is due to the exact size of the earth that allows the formation of life on earth (Harun, 2000).

\subsection{Occurrence of Day and Night}

\subsubsection{Definition of Occurrence of Day and Night}

The occurrence of day and night are amongst the signs of greatness of Allah SWT. This is because, day and night are a common phenomenon that a survival process for all beings in the world (human, animals, and plants). In that way, Allah SWT always tells about the occurrence of day and night to invite humans to think about this nature by an extraordinary substance. Day and night events occur because of the rotation of the earth. Due to this factor, some area of the sun-shielded the earth is darkness, which is called 'night' while the area of the earth exposed to sunlight is called 'day'. This process occurs as the earth rotates on its orbit at the cos angle (28.59) while rotating around the sun (Aleevia, 2013).

\subsubsection{Occurrence of Day and Night According Quran}

Surah Al-Furqan verses 47 and 62 mentioned about the occurrence of day and night:

"It is He who made for you the night as a covering and sleep for rest and He made the day a recall to life" 
(Surah Al-Furqan verse 47)

This verse proves the power of Allah SWT which is the presence of sunlight starting from rising to sunset is connecting with day and night. In addition, the words "the night as a dress and sleep for rest" explains that all occupations or activities will be delayed so that humans can rest and collect energy for the next day's work.

"It is He who made the night and the day alternate for one who desires to take admonition, or desires to give thanks" (Surah Al-Furqan verse 62)

Thahir ibn 'Asyur argues that this verse provides that every person should think about the occurrence of day and night. Besides, Sayyid Quthub interpreted this verse on how great the power and precision of His arrangement. "Earth rotates on its orbit once every 24 hours or about a thousand miles per hour. If the earth is only rotating only at $100 \mathrm{~km} / \mathrm{h}$, then the night and the day will be longer than the original condition. The sunlight will burn all life on earth during the day and freeze it at night. So verily Allah SWT has bestowed His grace and kindness upon His creatures. This is what people should be pondering and grateful" (Al-Haqqu, 2015).

\section{CONCLUSION}

There are many miracles found in the Quran as Allah revealed to the Prophet Muhammad SAW to be distributed to human so that people are impressed with the greatness of Allah SWT. Quran and science are inseparable. This is proved with every scientific information written in Quran when scientifically studies will find the amazing results. In other words, all the scientifically studied is same and parallel to what is mentioned in the Quran.

As in the example in Surah Ar-Ra'd verse 3, Allah tells about the earth, the mountain, the river and the occurrence of day and night is a greatness for those who think about it. The creation of earth, mountains, rivers and occurrence of day and night is a sign of greatness that shows the existence of God, Allah SWT. With the existence of mountains as a peg and water storage, the earth can stand strong and allows living things to keep alive. The unique creation of Allah SWT and the things created by Allah SWT are all related to each other.

In addition, the occurrence of day and night is amongst the many signs of greatness of Allah SWT as Allah SWT creates the universe with a balanced state that supports life and becomes a human being as a caliph on earth so that human beings would be responsible to manage this earth well and keep the earth in harmony. The researcher hopes that Muslims do not forget that science is a sign of the greatness of Allah SWT. With the links of Quran and science, it allows people to be more interested to approach, read and tadabbur Quran accordingly.

\section{ACKNOWLEDGEMENT}

Sincere gratitude and appreciation to those who contribute to this research. The researcher would like to acknowledge Research \& Innovation Management Centre (RIMC), Universiti Sains Islam Malaysia (USIM) for the management and Mr. Farhan for the article editing and Ms Shahirah Sulaiman for the language checks.

\section{REFERENCE LIST}

\section{Al-Quran Al-Kareem}

Abdul, R. R. (1996). Alam semesta. Jakarta: FE UI

Ahmad, H. (2011). Keseimbangan penciptaan bumi menurut Al-Quran dan sains. (Master's thesis). Universitas Islam Negeri Syarif Hidayatullah, Jakarta, Indonesia

Aleevia, S. (2013). Kejadian siang dan malam. Retrieved from https://www.scribd.com/document/143642289/Kejadian-Siang-Dan-Malam

Al-Haqqu. (2015). Kejadian siang dan malam. Retrieved from https://alhaqqublog.wordpress.com/2015/10/05/kejadian-siang-dan-malam/

Allan, S. (2015). Geologi dasar pembentukan bumi. Universitas Proklamasi 45, Yogyakarta, Indonesia

Budianto. (2006). Risalah alam semesta dan kehidupan. Jakarta: G-kreatif 
Celik Tafsir. (2017). Tafsir Surah Ar-Ra'd Ayat 1-3 (kuasa mencipta Allah) Retrieved from https://celiktafsir.net/2017/02/10/al-rad-ayat-1-3/

Cowan, J. M. (Ed.). (1979). A dictionary of modern written Arabic (4th ed.). German, Wiesbaden: Otto Harrassowitz

Danial, Z. A. (2014). Quran saintifik edisi kemas kini. Retrieved from https://pts.com.my/buku/quran-saintifikedisi-kemas-kini/

Fuad, T.I. (2016). Konsep gunung dalam Kitab Al-Jawahir Fi-Tafsir Al-Qur'an Al-Karim perspektif sains modern (Master's thesis). Universitas Islam Negeri Walisongo, Semarang, Indonesia.

Harun, Y. (2000). The creation of the universe.

Ibn al-Mandhur, Lisan al-arabi,Jilid 1, Kairo Daar al- Ma'arif

IImu Geografi. (2016). Pengertian bumi dan lapisannya. Retrieved from https://ilmugeografi.com/ilmubumi/pengertian-bumi

Lajnah Pentashihan Mushaf Al-Quran. (2010). Penciptaan bumi dalam perspektif Al-Quran dan sains

Lerner, K. L. \& Lerner, B. W. (2005). U X.L Encylopedia of water science. USA: Thomson Gale

Linda, N. (2012). Struktur lapisan bumi. Universitas Sebelas Maret, Surakarta, Indonesia. Retrieved from https://www.scribd.com/doc/88118483/Struktur-Lapisan-Bumi

Nadiah, T. (2013). Sains dalam Al-Quran. Abu Dhabi: Dar-al-zaman

Rizki, F. (2016). Teori penciptaan bumi dan langit dalam tafsir al-jawahir karya Tantawi Jauhari. (Master's thesis). Universitas Islam Negeri Sunan Kalijaga, Yogyakarta, Indonesia

Samir, A. H. (2015). Ensiklopedia sains islami. Bandung: PT Kamil Pustaka

Stuart, J. G. (2008). Briefly noted: cambridge illustrated dictionary of astronomy, by Jacqueline Milton. Sky and Telescope.

Udi, Y. (2011). Al-tafsir al-ilmi antara pengakuan dan penolakan. Journal Khatulistiwa, 1(1), 34-43 